\title{
Civilisation and Economic Recession as Retardants to Communication Inherent in Efe, Gelede and Zangbeto Total Theatre Performance: The Cultural and Creative Arts Overview
}

Kojusotito Olatunji Idowu\& Mufutau Oluwakemi Oriola https://dx.doi.org/10.4314/jrhr.v13i1.12

\section{Abstract}

This paper examined economic recession and civilization as retardants of Efe, Gelede and Zangbeto traditional annual propitiatory festivals among the Yewa, Anago and Gun people of Southwest Nigeria, notable with total theatrical performances. The festivals aimed to control social vices and cleanse the community by exposing culprits who faced the consequences. Interviews were conducted on adherents and findings showed that lack of sponsorship and superimposition of Western beliefs have retarded the celebrations, evident in low-key practices with less theatrical performances. The paper suggests that government should improve on these traditional practices for the security and well-being of the society.

Keywords: Efe, Gelede, Zangbeto, Social vice, Civilisation, Economic Recession

\section{Introduction}

The present African generation is, and the upcoming ones will be missing a lot of the communicative values inherent in traditional African propitiatory ceremonies in the name of Western-acclaimed civilisation. Western education truly allowed civilisation to emerge but it is fraught with considerations that subjugate the traditions and beliefs of Africans. This paper is motivated by the forgotten legacies inherent in traditional beliefs that kept society afloat in the right 
Idowu \& Oriola: Civilisation and Economic Recession as Retardants to Communication Inherent in Efe, Gelede and Zangbeto Total Theatre Performance: The Cultural and Creative Arts Overview

direction before the introduction of Western education to the Yoruba and other tribes of Nigeria. Before the so acclaimed civilisation, there has been progressive camaraderie relationship among the Yoruba and other tribes in Nigeria through the use of spiritual and religious ceremonies, which have been used as tools to settle disputes, control vices, trace disputed family genealogy and give succinct historical accounts on controversial communal matters. This legacy is reposed in Yoruba people as a tradition to be transferred from generation to generation. Yoruba as a race in the South-Western Nigeria includes YewalAwori, Anago and Egun tribes. Gelede, Efe and Zangbeto celebrations were held supreme and made popular due to how it orally catalogued historical accuracy that controls vices among the citizenry through Efe (wit) griots, Gelede and Zangbeto with total theatrical performances.

Griots are historical personnel who lived close to the corridor of power to catalogue historical account orally and are considered masters of oral traditions. The griots in Efe memorabilia renditions can always contain information relating to physical or moral weaknesses of an individual, group, or community. Efe with cloned voice and masked face is no respecter of any personality, hence its operation at night. Efe is the custodian of history while its boldness to reveal hidden issues bordering on vices is noted for the support it enjoyed from its god-mother called iya, whose adherents appeased regularly through propitiatory sacrifices that include a variety of food supplies, dirge, music, dance, wit, mask-wearing, costume and specialised drumming.

Gelede and Efe are celebrated simultaneously as one because their functions are interwoven in order to achieve communication and cultural goals. The celebration of Gelede in the day time attracts theatrical performances to whet the appetite of the audiences before exposure made by Efe the previous night is made public with 
customised songs that expose individuals culpable of social vices in the community. Another feature is the belief that both Gelede and Efe are offspring of the same parents whose dire need for children resulted in celebration that engendered their pregnancy and thereafter child birth. Efe operates in the night to bring to limelight disputed historical issues and uncover hidden vices, while Gelede appears in the daylight to put up theatrical shows to settle disputes, attend to and bless barren women on their requests and warn perpetrators of social vices, which usually is the climax of the year's celebration. This celebration serves as a means of putting together social events to chastise wrongdoers and promote good virtues, thereby serving as not only a communicative avenue to expose wrongdoing but also a corrective tool to engender good conducts. It goes ahead to promote communal sanity through control of social vices, invocation of the ancestral spirit for child birth and prosperity for the entire citizenry.

Zangbeto is different from Gelede and Efe but with similarity in goals. It is regarded as a traditional voodoo that guides the night among the Egun tribe in Yorubaland of Nigeria and it is found in the Republic of Benin and Togo. Its adherents believe that Zangbeto watches the night instead of recruiting night guards in areas where they reside. Zangbeto is highly revered and it functions as unofficial society police force that controls social vices. It parades streets to watch over activities and events, with the intent of discovering and tracking down criminals who are hidden in the mist of the society to perpetrate evil. It is originally created to reprimand and scare the enemy away and that is why it wanders around to detect thieves and witches so as to enforce law and order (Butler Silas 3). Zangbeto masquerades look like a haystack. Butler Silas (4) observes that they are able to fall into trance which, according to tradition, enables their bodies to be inhabited by spirits who possess special knowledge of the people's actions. It is for these reasons the adherents believe that there is no human in the haystack but the spirit. Zangbeto is a secret 
Idowu \& Oriola: Civilisation and Economic Recession as Retardants to Communication Inherent in Efe, Gelede and Zangbeto Total Theatre Performance: The Cultural and Creative Arts Overview

society that allows for issues to be investigated even without the awareness of those concerned. Members of the society usually engage in trance that fortifies them with magical power to decipher secret vices in the society. This magical power helps in unraveling social vices committed in secret and this makes people to dread the masquerade.

The fact that the aforementioned traditional ceremonies are fast going into oblivion while social vices are on the increase calls for concern. The communicative and corrective purposes of Gelede, Efe and Zangbeto have in the past contributed to societal sanity. Their gradual extinction as a result of Western-acclaimed civilisation and the prevailing economic recession could thus be inimical to the wellbeing of the communities where they are domiciled. This research paper therefore examines how Western-acclaimed civilisation and economic recession have retarded these traditional celebrations in Yorubaland of Nigeria, thereby leading to their gradual extinction, with the resultant effects of increased social vices.

\section{Culture and Society: The Implication}

There is a relationship between class and culture. There is no monolithic or very dominant ruling-class ideology in human society. In his theory, Raymond Williams in the book Culture and Society theorized that:

...cultures are not the automatically determined products of class structures. Rather, they are actively created by people who are responding to their economic circumstances (231).

He draws a distinction between the people and the emergence of their cultural beliefs. He criticised the Marxist for narrowing their concern on culture to only art and literature. He said that culture should be regarded as total way of people's life which is a general social process. Departmentalised culture cannot suffice because whether one 
is a working class or not does not affect the transmission and effect of culture at all. The culture of a society is binding on all the citizens of that society except individuals consider themselves as deviants who the society usually sanctions. In a comparative theory of Raymond William and that of Dwight Macdonald, the latter classified culture into folk art, high culture and mass culture. Macdonald comments that folk art is the culture of the common people in pre-historic societies. It is spontaneous and autochthonous expression of the people shaped by themselves, pretty much without the benefit of high culture. He argues further that high culture is seen as the product of great individuals who are able to produce work that appeals to a minority who can appreciate work of this caliber. This implies that high culture should carry everybody along in understanding how it applies. He concludes that mass culture is a standardized and commercialised kitsch imposed by business on the masses to make profit and it does not express genuine culture in the way other classes have addressed culture. Macdonald criticized mass culture as a way to create a single, homogenised culture. In addition, high culture would be vulgarised and incorporated in a simplified form into mass culture. As an example, Macdonald Dwright in his book The Theory of Mass Culture comments that the high culture of the theatre was undermined by the mass culture of the cinema (137-139). This implies that when cinema came to the scene of entertainment, it overshadowed the popularity enjoyed overtime by live theatre performance. Cinema can be classified therefore under high culture which was the choice of the elite in the society. The theory cascades that high culture as it affected the choice of cinema over live theatre has been unconsciously applied to the exigent formation of Efe, Gelede, and Zangbeto cults as means to control the perpetration of vices in the society before the advent of colonisation and the so called civilisation in Africa. 
Idowu \& Oriola: Civilisation and Economic Recession as Retardants to Communication Inherent in Efe, Gelede and Zangbeto Total Theatre Performance: The Cultural and Creative Arts Overview

\section{Efe, Gelede, and Zangbeto as Potent Traditional Vices Detective}

Theatre is the branch of performing arts that concerns itself with acting out a story in full glare of an audience. In the process of accomplishing this, performers combine speech, gesture, music, dance, sound, and spectacle to communicate and carry out the content of a story in both audible term and action. Beginning from the ancient time, propitiation ceremonies were features of total theatrical performance that engendered the public declaration of loyalty to a god of choice. Dance always takes a large part of such propitiatory ceremonies because it constitutes dependence on social, cultural, aesthetic and moral condition of the society.

Gelede festival has witnessed tremendous patronage apart from the initial goal that sets it up. It is one of the biggest festivals in some Yoruba communities in Southwest Nigeria. It is full of funfair and fanfare with tong wagging side attraction. These ceremonies satisfy the description of what theatre or performing art contains. Performing arts are a form of art in which performers engage their bodies amidst other objects called props (properties) to transmit message to the audience. The history of performance is dated to when propitiatory sacrifices and ceremonies are done to commemorate what the gods have accomplished for the adherents over the years. It was a purposed propitiatory ceremony for the gods though this has changed to entertainment in contemporary period in relation to the theory of Macdonald of high culture. The content then has a goal that must be made paramount and this goal has to be monitored until it is achieved. In the process of propitiatory performance then, it often exhibits dance, music, opera, theatre, musical theatre, magic, illusion, mime, spoken words, dirges, panegyric citation, or recitation, public diction rendition on communal matters in dispute and specialised performance to differentiate the festival in parade or in procession 
from other similar propitiatory ceremonies. All these were usually exhibited during Efe, Gelede, and Zangbeto annual ceremonies. It is important to discuss the detail of the celebration's paraphernalia that the old performers paid unusual attention to in comparison with what is in operation now and the quest for doing it right without compromise even with people's improved civilisation, beliefs and economy empowerment.

\section{Historicity of Efe, Gelede and Zangbeto}

Efe Celebration: This celebration as mentioned above is usually held at night preceding the public outing of Gelede. Efe is predominantly restricted to parts of Yewa land in Ogun State, Nigeria. The Anago and Ketu people within Yoruba dominated area give great credence to the celebration of Efe because what it turns to accomplish within the society that practices it. Oral history from adherents confirms that Efe shares the same mother with Gelede and their mother was Yemoja. Yemoja had been barren for years and consultation made to Ifa oracle prescribed a dance with mask and some rites before she could conceive. She got pregnant after she performed the dance and the ritual. She gave birth to a male child and named him Efe (wit or humour) and later a female child named Gelede. Efe and Gelede are from the same parents. Gelede emphasizes song and jests which have become associated with her name. Gelede, like her mother, could not have children, and she was encouraged by Ifa to follow their mother's footstep by dancing with mask and performing some ritual at night. After the ritualistic dance, she conceived and gave birth herself. This process has since become part of their descendants' tradition till today. Efe was endowed with spiritual power to uncover hidden conducts that were detrimental to the coexistence of the people. This power was gradually developed to uncover hidden communal vices by the children and grandchildren of Efe until today (Lawal 27). 
Idowu \& Oriola: Civilisation and Economic Recession as Retardants to Communication Inherent in Efe, Gelede and Zangbeto Total Theatre Performance: The Cultural and Creative Arts Overview

Vices are perpetrated in hide-outs and the perpetrators think of not being able to be discovered having sealed all clues to its discovery. In the community where Efe is celebrated and glamorized, the case is different because no matter how the individual sealed the clue to vice discovery, Efe usually reveals the perpetrator and the vice committed. The way and manner the discovery is made still remains a mystery to non-adherents till today. This deity is revered for its enormous power of knowing the unknown. Efe operator clones his voice so that the revelation will not be insinuated or traceable to any particular individual. Efe in the process reveals situations of unimaginable scales to the general populace without considering the status of the culprit. The cover of the night makes it so powerful and a respecter of no personality at all. For example, in Ifonyintedo, a town in Ipokia Local Government of area of Ogun State, Nigeria, where Efe is celebrated, it recorded a situation where a woman went to the farm to meet a farmer in order to negotiate the supply for farm produce with him. In the process the man copulated with the woman on agreement and this for a time remained top secret between the two culprits. To the surprise of the two of them, during the following Efe festival, the situation was part of the revelation made in a night devoted to revelation of social vices. The story of the man and the woman's adulterous escapade was vividly told to the extent that the time, the day and the place where the vice took place were mentioned. The vividness of the revelation was convincing enough to embarrass the innocent spouses of both culprits. The shock of that revelation made the woman to disappear till today with no traceable information (product of an interview with Adesiyan David, 2017).

Another one was a man who stole a goat from a neighboring village where Efe does not cover, but he eventually sold it and came back home with the derivative largesse with intention that the vice has been cordoned from Efe's attention. To his chagrin, Efe made the 
revelation during the same festival. The revelation was so detailed and concise that the perpetrator was stupefied in the process. Perpetrators of vices were never allowed to go scot-free without commensurate punishments. When this was on, it was noticed that the rate of social vices reduced to the barest minimum before now. Efe operates in the night and the costume and other outfits are simple. However, it required commitment, faith and economic uplift to keep the process going. Operation fund has been the responsibility of the people. Many adherents are farmers and that is the reason the celebration is made after the yearly harvest so as to have enough fund, food and props for the festive ceremony.

Gelede Festival: It has been discovered that most Yoruba mythologies take their origin and foundation in the divination narratives known as Odu Ifa. It has been observed that many ifa verses (ese ifa) emanated from the problems of the people and the proffered solution. Gelede festival came from a solution proposed to Yemoja the mother of Gelede for her plight as a barren woman (Lawal 28). Yemoja gave birth to Gelede after the mother had performed the ritual and danced with mask. Gelede festival comes up every year to better the lot of people and to control vices. It is also celebrated to cleanse the society of pestilence, induce rainfall, enrich human fertility and all these were made possible through supernatural power of Iya (mother's spirit). The festival usually begins with all-night Efe mask dance in which it uses satire to entertain and educate, and that is why didactic themes are major occurrence of Efe songs. Because people and the adherents stay overnight for Efe dance, they go home to sleep in preparation for the afternoon dance by Gelede. This is usually staged at market square where dancers are engaged with vigorous drum beat along with Gelede masquerade (Birmingham Museum of Arts 71). 
Idowu \& Oriola: Civilisation and Economic Recession as Retardants to Communication Inherent in Efe, Gelede and Zangbeto Total Theatre Performance: The Cultural and Creative Arts Overview

The festival is always spectacular because Gelede dance display goes along with use of different colourful masks that represent groups, village or where the Gelede in display domiciles (see plate 1 and 2). The mask is more accurately in form of a headdress, since it is made to rest on the head to cover the face of the wearer which is further veiled with transparent velvet (see plate 3). Siegmann, Adande and Dumouchelle conclude that:

...the headdress takes the form of a human head, on top of which are motifs that are intended to entertain onlookers but, in addition, usually address social concerns that may also be expressed in songs that are part of the masquerade. The headdresses are usually brightly painted. (34)
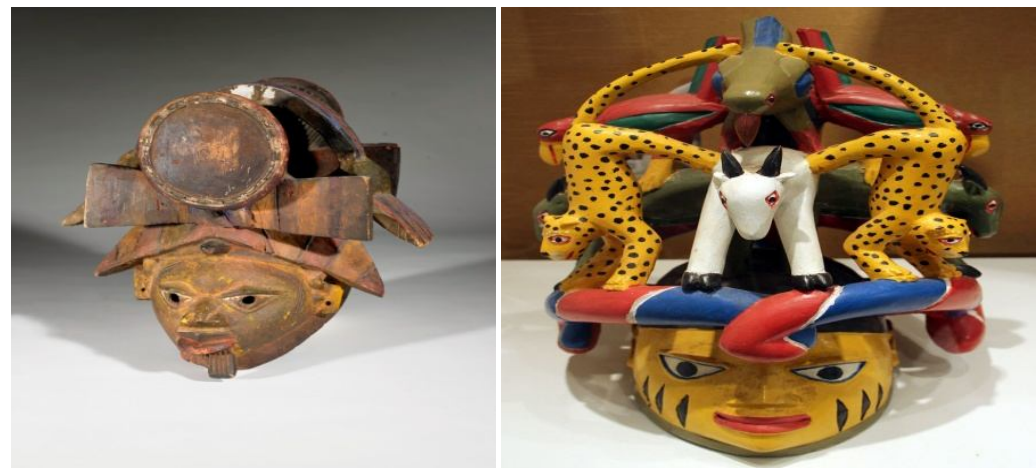

Plate $1 \quad$ Plate 2

Gelede Mask (Birmingha museum)Gelede Mask (Afro-Brazil Museum) 


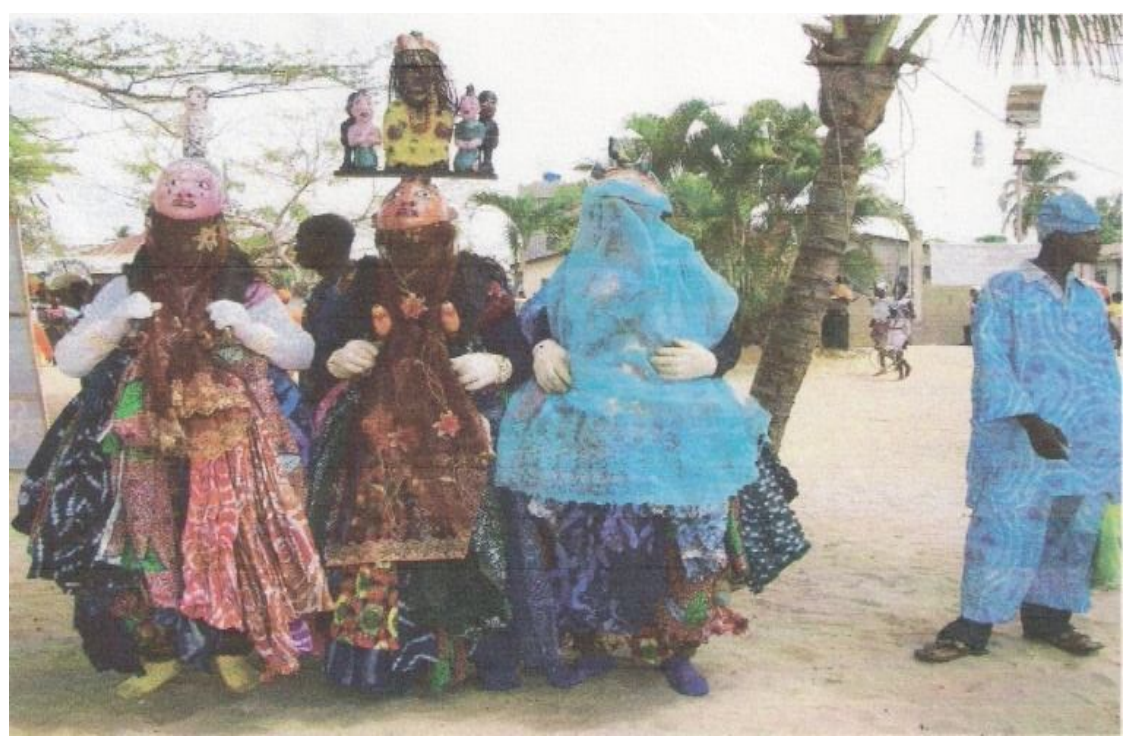

\section{Plate 3}

Gelede-masquerade at an annual festival. They are costumed with headdress and veil to prevent identity (Photo in Badagry)

The costumes are assorted in nature to also display wealth, affluence, and popularity. Lawal (27) observes that the headdress is to the costume what the head (ori) is to the human body. It is an index of identification and the essence of the masker's personality as long as he is inside the mask. In spite of the comical representation that often appears on the headdress, the face below the superstructure remains serene, as if stressing the paradox of life and the need to live life with special care. There are other add-ons used to garnish the appearance of the mask wearer, which portray that the adherents are children bearers. Local children toys are conspicuously displayed with enough rattles accompanying the dance steps. The display of Gelede combines communication art, visual art, ritual, dance, and theatrical 
Idowu \& Oriola: Civilisation and Economic Recession as Retardants to Communication Inherent in Efe, Gelede and Zangbeto Total Theatre Performance: The Cultural and Creative Arts Overview

display. The celebration is aimed at honoring mothers. Because of this, vice perpetrators are the main themes for composing its music or song with stern warnings to them to desist from their nefarious activities that serve as threats to mothers and their children. The reason it is so is that mothers care for their children and any social vice that will affect the peaceful existence and growth of their children is discouraged. In many Yoruba communities, this goal is what Gelede festival accomplishes. In their contribution, Siegmann, Adande and Dumouchelle says that:

Gelede celebrates mothers (awon iya wa), a group that includes female ancestors and deities as well as elderly women of the community, and the power and spiritual capacity these women have in society. However, this power may also be destructive and take the form of witchcraft. Therefore, Gelede serves the function of appeasing this power as well. (35)

Gelede ceremony is well organized with careful choreographed dance, singing and music with specialized drumming that is proverbial and message-oriented. Gelede itself is attuned and knowledgeable with the message of the drum that is why the dancing steps are in consonant with what the messages of the drums are. However, the festival targets women but the performances are done by men who at times pair to represent both genders as the display unfolds (see plates 5, 6,7and 8). The wearing of mask is an important aspect of the dance and the masks are in both male and female facial outlook. Birmingham Museum of Art (71) adds that the pair of men masquerades as women is to amuse, please and placate mothers who are considered very powerful, and who may use their powers for good or destructive purposes. The powers are especially linked to childbirth. The abilities they possess may be activated either consciously or unconsciously during the staging of this propitiatory ceremony. 


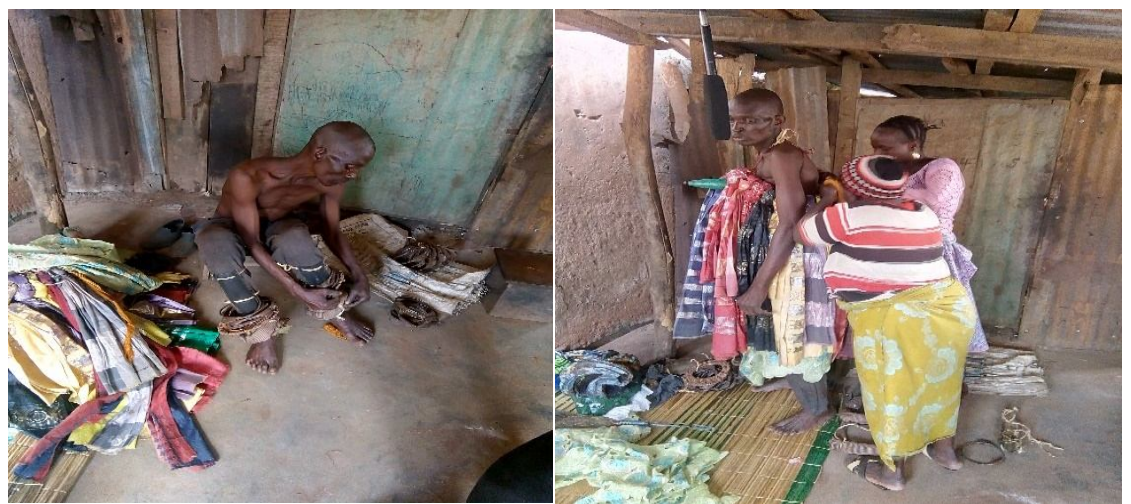

Plate 5

Plate 6

Gelede masquerader arranging props Gelede is the masquerade of women for men. and costume for performance outing These women are dressing themasquerader (Ilaro). up for a performance (Ilaro).

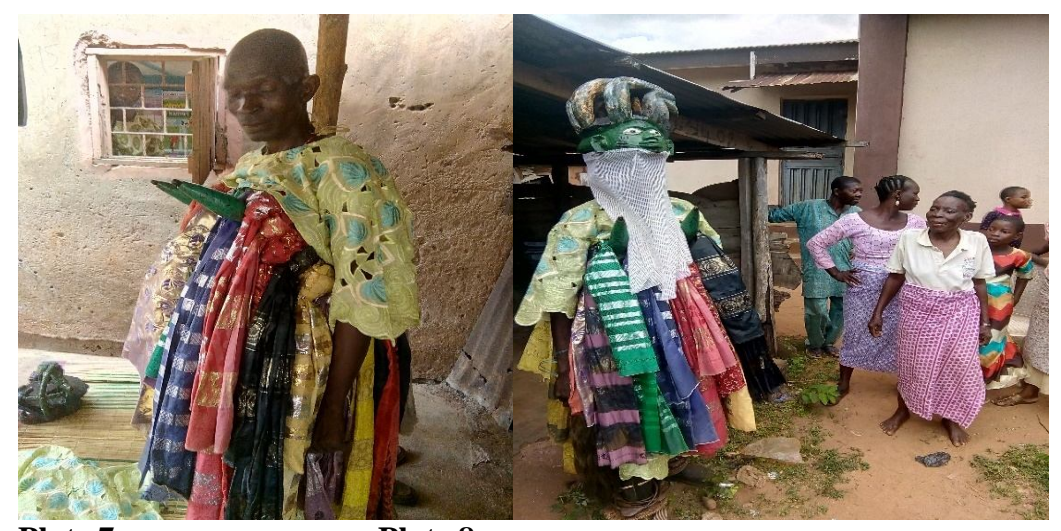

Plate 7

Plate 8

Half-dressed Gelede masquerade of a Fully dressed Gelede with protruding man in portrayal of female features.breast symbol to portray fertility inherent in women folks. 
Idowu \& Oriola: Civilisation and Economic Recession as Retardants to Communication Inherent in Efe, Gelede and Zangbeto Total Theatre Performance: The Cultural and Creative Arts Overview

Zangbeto Festival: Zangbeto is a masquerade costumed with haystack which has the ability to fall into trance. The name zan means night while gbeto means dweller. Zangbeto is therefore considered the spirit that dwells in the night. The power in the name as indicated enables their bodies to be inhabited by spirits who possess special knowledge of the actions of people. The adherents are made to believe and thereby advocate that there is no human under the costume made from haystack but only the spirit of the night. The traditional role of Zangbeto is to police the society and free it from miscreants. Butler Silas (30), adds that the adherents form a secret society which can only be strictly attended to by Zangbetos and when in trance are said to have magical abilities, such as swallowing splinters of glass without coming to any harm and scaring away even witches. The power of Zangbeto is revered and it is said to be equal to the power processed by vodun (voodoo) and this enables it to perform the role of community watch. The masquerades reprimand perpetrators of social vices who are brought to book during the festival in the full glare of the public. Its magical powers has been put to test and found to be potent to the extent that it can walk on water without sinking. Oyesakin Abiodun (166) agrees that Zangbeto first emerged as a group to protect the coastal township against external incursions. He argues further that a constant feature of the coast dwellers is the need to effectively defend their settlement against external aggressors from the overseas and hinterland neighbors and the necessity to venture and attack others. Hunsu Folashade (6) comments on the usefulness of Zangbeto by saying that its position as vigilante was initially a traditional military organization responsible for defending the territorial borders of Badagry in Lagos Nigeria. This submission clearly depicts the role of Zangbeto in the lives of people. In all Gun communities, the head of this cult is Zangan (night captain). This is an elderly man who is tested and well respected by 
all members of the society. He is to intervene in sensitive issues of the society and as the representative of the people as well.

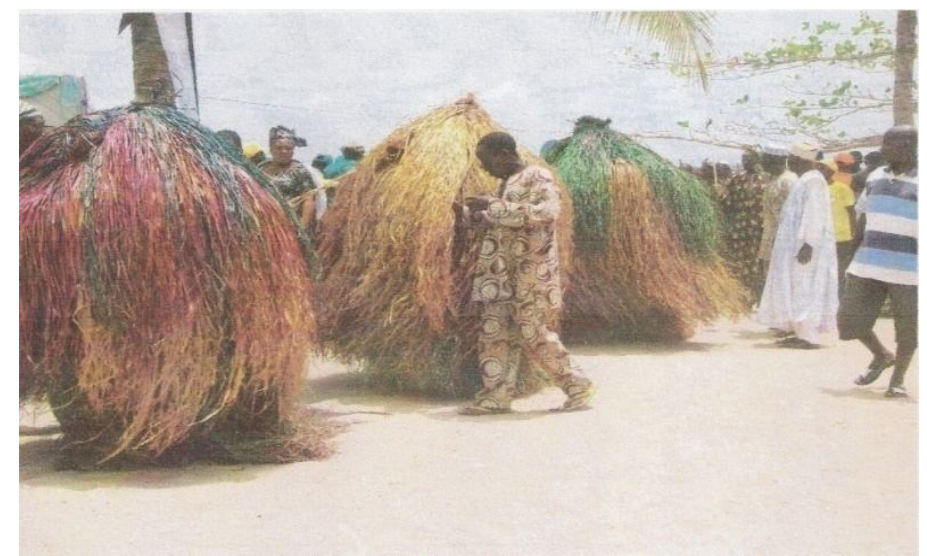

\section{Plate 9}

\section{Zangbeto Procession in Badagry, Lagos}

Like Efe and Gelede, Zangbeto apart from the major night watch, gives way to a more pervasive promotion of cultural values and heritage: the audience is treated to the entertaining sight and sound of typical Gun cultural dance, music and spectacular masquerade performance (Hunsu Folashade 7-8). It is believed that Zangbeto is a spirit that cannot be seen but has feelings that could be angered if the tenets are broken. The wrath of Zangbeto should not be tested hence its competence to keep adequate night watch and fetch-out vice perpetrators. It has ideals or morals that make him abhor whatever goes contrary to what it favours. Morality is one of the major concerns of the deity. It goes to reprimand those who abdicate their responsibilities for frivolities. It is said that a man is not a man enough if he cannot fulfill his obligations to his family; likewise a citizen who defies societal ideals for vice is not a man to be found walking in the society freely. Zangbeto punishes culpable individuals 
Idowu \& Oriola: Civilisation and Economic Recession as Retardants to Communication Inherent in Efe, Gelede and Zangbeto Total Theatre Performance: The Cultural and Creative Arts Overview

with severity. It is also dependent on what the spirit tells Zangan to administer as punishment for the vices committed by the apprehended culprit. Zangbeto is so dreaded that perpetrators of vice are careful to cross its part.

\section{Civilisation, Economic Recession and the Performance of Efe, Gelede, and Zangbeto}

Civilisation takes an average African man away from the continental value of dignity of labour as a means of wealth generation and attaining vice-free economic status. Most vices have been on the increase because society gives undue honour to ill-gotten wealth. Even when people know that the wealth of a man is not commensurate to what he does, the society honours such an individual with religious and cultural chieftaincy titles. The so called civilisation has beclouded the sense of reasoning of an average Africans to the extent that in the name of civilisation what the society abhorred in the past is what it uses as entertainment now. Breeding of decadent society through the Western-acclaimed civilisation has overshadowed good and acceptable norms of the society Africans are known for some decades ago. The decadence has so eaten into the fabrics of good character to the extent that going against the tide is considered as still living in dark age. This new found behaviour has made the society to become unsafe for habitation. The societal leaders are no more responsible to enforce the traditional rules governing society because they are not accountable to anyone. If people are accused of doing the wrong thing, the defense in the name of civilisation is that the accuser is trying to trample on the rights of such persons as citizens. Civilisation against African cultural check in place is killing the citizens with no one to rescue them as it was in the traditional era. Arguably, not the entire traditional African cultural practices are sane for the society but culture is dynamic and the good 
cultural practices such as Efe, Gelede and Zangbeto can be refined for the purpose of sanitizing the society. Bad economic situation of people is another contributing factor that makes social vices to become almost uncontrollable. Recession affecting people's economic life does not allow them also to think straight. This is seriously affecting the sense of judgement to identify what is good which is seriously affecting vices control in the society.

From the standpoint of economists, economic recession is the significant decline in economic activity spread across the economy, lasting more than a few months, normally visible in Gross Domestic Product (GDP), real income, employment, industrial production and wholesale-retail sales. Economic recession becomes noticeable when it affects growth rate for two consecutive quarters and from the definition, Nigeria can be considered to be on economic recession in recent times between 2015 and 2017, and in the later part of 2020. Economic analysts have consistently bamboozled Nigerians with jargons to define the state of economy, but what the ordinary man on the street knows is that it is harder to put meal on the table of average Nigerians. High inflation rates resulting into low purchasing power, accumulation of foreign debt, high interest rate for investors, devalued currency, loss of confidence in government and massive unemployment are the militating forces against the economy which force it into recession. The unchecked activities of vices perpetrators such as internet fraudsters, armed robbers, marauders and incessant attack of Fulani herdsmen on farmers who are trying to practice their legitimate business have aggravated economic hardship and brought untold living conditions. The resultant effect of these has been the involvement of people in various vices.

How does the economy recession affect the total theatre practice of Efe, Gelede, and Zangbeto aimed at vice control? Apart from modern religious beliefs of many Nigerians that first nailed the African cultural development to a coffin, lack of good economic life 
Idowu \& Oriola: Civilisation and Economic Recession as Retardants to Communication Inherent in Efe, Gelede and Zangbeto Total Theatre Performance: The Cultural and Creative Arts Overview

is another factor militating against the cultural practices. The vice promoters are now overwhelming the anti-vices campaigners in the society. The get-rich-quick syndrome has disillusioned people from the traditional African ideals. Adherents who have received one particular blessings through the propitiatory ceremonies held in the past solely sponsored most of the activities of these deities' festivals. It is obvious that the reversed is now the case, as people no longer seem to receive any blessing and for that reason, allegiance to these deities has been reserved. The activities of these deities have witnessed restriction since the adherents are dwindling yearly on the basis of beliefs and civilisation factors. Another noticeable service they formerly rendered has been taking over by government agencies, which benefits illegality from vices' perpetrators in the society. Government attempts to solve Africans spiritual problems with foreign civilisation dictate that may not work to curb vices. For instance, if a woman is accused of witchcraft she used in taking somebody's life, how does one prove this in a law court? But even an African judge knows clearly that this thing exists, but the Western law does not hold one accountable without tangible evidence. If such a culprit is taken to Efe, Gelede or Zangbeto, the mystery will be unraveled traditionally. However, the value of these traditional means has been usurped by acculturation process which eventually devalued the cultural process beyond repair.

In an unscheduled interview with a chieftain of Zangbeto Mr. Taiwo Posu (a zangan), on what he observed about the reason the value of Zangbeto within the society is no more as it used to be, his response began with a Yoruba philosophical statement that A ko le daba leyin owo, nitori owo nikeke ihinrere (There is nothing that could be accomplished without fund because good news is hinged on funding). He continued that "before the economy goes into comatose, people come for yearly festival with thanksgiving items and money 
which were used to foot the bills incurred during the festival but now, new religion has made people to distance themselves from Zangbeto and other traditional deities". He alarmed that "vices are now accorded with sophistication which needs huge funds to battle it. He posited that "if government that has unrestricted access to funds complains of not having enough to solve her problems, ours is a pitiable condition. The role played by these deities has been stopped with undue bankrolling of vices from political powers, unless they are at the cross road no one in government remembers us", he concluded. Chief Folu Fashola who met the researchers in the discussion added that as a Chief Priest of Efe clan, he had been lamenting the trend of events for some time now because the adherents were not dreaded again about the revealing power of Efe. "The decadence has enveloped so many adherents for worse situation of attitude towards ideal. The rites are now overlapping because of paucity of funds to perform them. Many community leaders have professed foreign religion to the detriment of the traditional ones" he said. He therefore concluded that "the way the economy bites debars adherents from giving their Gelede masks and costume facelift as recompense for negligence the gods who are unhappy. We all know what it means for the gods to be unhappy and the consequence on the people and society. He concluded that the costumes of past years are what they recycle and they have lately turned to rags that dishonor the adherents. Going by the negligence of a deity meant to be venerated and propitiated for by old people due to civilization and economic hardship, it is clear that the end to that deity is imminent" was said as his parting shot.

These experiences show that civilisation, new religious beliefs and economic status of the people have reflected negatively on the exhibits of total theatre, which usually form part of propitiation ceremony of Efe, Gelede, and Zangbeto among Yewa, Anago and Egun people of Southwest Nigeria. This has therefore become a 
Idowu \& Oriola: Civilisation and Economic Recession as Retardants to Communication Inherent in Efe, Gelede and Zangbeto Total Theatre Performance: The Cultural and Creative Arts Overview

reminiscence of a glorious past in a devalued way which supposed to have engendered social cohabitation for Africans with enviable safe society. Communication and rites emanating from all these practices have gone into oblivion unless people read them in books, which is part of the focus of this article. There is need for new civilisation that is fashioned after African cultural and traditional means.

\section{Conclusion}

Civilisation and inherent economic recession in Nigeria have affected so many ideals that could be preserved in the country. The government policy benefits only the affluent and impoverished ones are left in the peasantry. In the traditional African society, the society thrived because of promotion of sanity among the people. There were measures put in place to checkmate people from promoting and perpetrating social vices. The peasant economy of people was able to cater for their deities to the extent that no one remembered any threat to their lives. In an indigenous African setting, the leaders have devised means to foster peaceful coexistence through dreaded deities to curb vice promoters. Most of these deities were used for wallwatching in the community, while they are also meant to preserve people from external incursion and marauders.

Efe, Gelede, and Zangbeto have records of monitoring and watching over the society to secure the citizens from external and internal vice perpetrators. This has been done successfully over time and scholars have corroborated the usefulness of these deities. Reason for their not being used now is not unconnected with the civilisation and economic downturn in the country. Raymond Williams commented on the emerging societal culture as dependent on the attitude of people, while Macdonald Dwight classified culture and rendered why high culture is necessary for development of all and sundry but he was of the opinion that both folk and mass cultures are 
relative to affluence in their operation. High culture is the type that applies to functionality of Efe, Gelede, and Zangbeto in the way they cater for all and sundry in the society. Despite the challenge of economy, these cultural practices are still being revered and maintained skeletally within their areas of operation. The need to nationalise some of these inherited cultural festivals of Africa is due now than ever because of the trends of vices within the society. Government should revisit their usefulness, refine and apply their process to solve security challenges being witnessed on daily basis in Nigeria.

\section{References}

Birmingham Museum of Art. Birmingham Museum of Art: Aguide to the Collection. 2010. Online. Retrieved from the 30 August, 2017 $<$ http//amazon.co/berminghammuseum/geledemask>

Butler, Silas.. Benin, Guilford. Connecticut: Dradt Travel Guides, The Globe Pequot Press, 2006.

Hunsu, Folasade. Zangbeto: Navigating Between the Space of Oral Art, Communal Security and Conflict Mediation in Badagry Nigeria. Uppsala, UK: Nordisca Afrika Institutet 2011.

Lawal, Babatunde. The Gelede Spectacle: Art, Gender, and Social Harmony in an African Culture. Seattle: University of Washington Press. 1996. Print

Macdonald, Dwright. "A Theory of Mass Culture". In Rosenberg, Bulkks. and White, Donald (eds.) Mass Culture: The Popular Arts in America. pp. 250-267 1957.

Siegmann, Waffersen C.; Adande, Joshua.and Dumouchelle, Kenneth. D. African art a century at the Brooklyn Museum. Brooklyn, New York: Brooklyn Museum, 2009.

Oyesakin, Abiodun. Preliminary notes on Zangbeto the masked vigilante group among the Egun in Badagry. Badagry: A study in history, culture and tradition of an ancient city. Ed. Ogunremi, 
Idowu \& Oriola: Civilisation and Economic Recession as Retardants to Communication Inherent in Efe, Gelede and Zangbeto Total Theatre Performance: The Cultural and Creative Arts Overview

Olu. Ibadan: Rex Publication and Syndicate Communications. pp. 165-75 1994. Print

Williams, Raymond. Culture and society. Penguin: Harmondsworth, 1961.

\section{Interviews}

Posu, Taiwo. Personal interview. 20 July, 2017.

Fashola, Folu. Personal interview, 3 August, 2017.

Adesiyan, David. Personal interview, 10 August, 2017

\section{Photo Credits}

Birmingham Museum of Art https://en.m.wikipedia.org/geledemask, 2010. Plates 1 and 3.

Facedetruth Edutainment and Media System, Plates 2 and 4.

Pictures taken by the researcher in Gelede shrine at Ilaro, Ogun State, Plates 5 to 8

Kojusotito Olatunji Idowu (PhD) is alecturer in Department of Creative Arts, College of Humanities, Tai Solarin Universityof Education, Ijagun, Ijabu Ode, Ogun State.

Mufutau Oluwakemi Oriola (PhD) is a lecturer in Department of Creative Arts, College of Humanities, Tai Solarin University of Education, Ijagun, Ijabu Ode, Ogun State. 